\title{
The evolution of triple junctions: from failure to success
}

This paper is a non-peer reviewed preprint submitted to EarthArXiv

Hany M. Khalil a,b, hany.khalil@monash.edu; geo.hmk@alexu.edu.eg

Fabio A. Capitanio a , fabio.capitanio@monash.edu

Alexander R.Cruden a, sandy.cruden@monash.edu

${ }^{a}$ School of Earth, Atmosphere and Environment, Monash University, Clayton, Australia

${ }^{\mathrm{b}}$ Department of Geology, Alexandria University, Moharam Bey, Egypt 


\section{Abstract}

9 Divergent triple junctions are stable plate margins where three spreading ridges meet. Although it is accepted that this configuration is inherited from an earlier phase of continental rifting, how post-breakup triple junctions emerge from the separation of two plates remains unclear. By documenting the strain rate history recorded in the three rift-arms of several modern and ancient triple junctions, we show that deformation is episodic and localized in only one or two rifts at any given time. We further investigate this behavior in threedimensional (3D) analog experiments of rifting, under a range of kinematic boundary conditions and containing a variety of pre-existing lithospheric heterogeneities. Deformation in the experiments is characterized by strain jumps and rift abandonment, comparable to natural observations. Boundary rotation during extension induces oblique stretching directions, along-strike strain gradients and forces significant strain jump to reduce the number of rifts segments active. Models that comprise lithospheres ranging from homogenous to containing a triple junction-like pre-existing heterogeneities, never developed a three-armed rift, where all rift segments are active at same time, at any stage. Our experimental results indicate that, unlike mature, successful, and stable oceanic triple junctions, early-stage continental rifting progresses through unstable "double-junctions" characterized by repeated strain jumps and rift failures and reactivations.

\section{Introduction}

Triple junctions play a critical role in the force balance that drives plate motions through time. They control the continental segmentation and the morphology and the evolution of oceanic basins. Oceanic divergent triple junctions are the most stable and long-lived configurations (McKenzie and Morgan, 1969). They originate as three rifts (R-R-R) or two rifts and a transform fault (R-R-F) in continental realms, while in their mature stage, they evolve into triple oceanic ridge or ridge-transform configurations. The emergence of stable, mature oceanic triple junctions from the fragmentation of continental lithosphere has not yet been explained by the paradigm of continental rifting, which hinges on the formation of sub- 
linear rift structures between two diverging plates. Divergent triple junctions' formation and evolution remain speculative. They cannot be explained by two-dimensional (2D) rifting models and are not easily reconciled with large-scale, time-averaged plate kinematics derived from seafloor spreading anomalies and kinematic data (e.g., Gordon 1995; Wolfenden et al. 2005). Therefore, when, and how continental rifts become oceanic triple junctions remains an unsolved question in plate tectonics.

A long-held view of divergent triple junctions invokes initial doming of continental lithosphere above a mantle plume-head as a cause for their initiation and subsequent outward rift propagation (Burke and Dewey, 1973). However, this hypothesis has been questioned by more recent geological, geophysical, and numerical modeling studies. Many continental divergent triple junctions are associated with mantle plumes where rifts propagate inwards, towards the area of mantle plume impingement, for example in the case of the Afar triangle and South Atlantic rifts (Wolfenden et al., 2004; Koopmann et al., 2014). Burov and Gerya (2014) showed that mantle plume impingement beneath a stretching lithosphere does not produce a triple junction, and only linear rifts form. Mantle plumes weaken the lithosphere (Bellahsen et al., 2006), and related uplift generates a radial extensional stress field (Davies et al., 2019; Moucha and Forte, 2011). However, the development of many divergent triple junctions is not associated with a plume head (e.g., South Australia, Labrador-North Atlantic, South Sinai), ruling out mantle plumes as requisite features (Peace et al., 2017). In general, many natural examples of divergent triple junctions appear to have developed on pre-existing thermal and mechanical heterogeneities in the lithosphere, which significantly impact the propagation, orientation, localization, and distribution of continental rifts in 3D (Heine and Brune, 2014; Molnar et al. 2017). Although, the influence of these pre-existing structures on the development of triple junctions remains unknown.

Our understanding of the long-term evolution of rifting relies on the sustained boundary forces which oriented favorably to the strike of the structures until eventual break-up. However, rifting in active divergent triple junction implies an extension in three directions which does not easily reconcile with the basic tenets of plate tectonics of two diverging plates. Boundary forces vary in magnitude during rifting, and also reorient continuously, ranging from orthogonal to non-orthogonal to rotational (Brune et al., 2014; Bellahsen et al., 2005), accounting for rift complexities, such as along-axis rift segmentation, rift jumps (Khalil et al., 2020) and associated magmatism (Koopmann et al., 2014) as well as the 
evolution of micro-continents (Molnar et al., 2018). For example, Koptev et al. (2015) successfully modeled a triple junction by enforcing extension from two perpendicular boundaries on a mantle plume-like weak seed. However, the arms of the triple junction in their model subsequently evolved simultaneously opposing natural examples, i.e., Afar triple junction (Wolfenden et al. 2004), where the triple junction's arms have distinct tectonic histories and evolve in different time frames.

Here, we calculated the vertical strain rate "subsidence" from some well-studied inactive "failed" continental divergent triple junctions where none, one or two rift-arms reach the break-up stage. Using 3-D analog modeling of lithospheric stretching and rifting, we systematically test the role of pre-existing heterogeneities and evolving boundary conditions on the formation and evolution of continental divergent triple junctions. Comparison of the results indicates that none of the continental triple junction cases we studied, or the analog experiments, agree with simultaneous evolution of three-rift arms within a triple junction rifting configuration. Thus, suggesting that oceanic triple junctions are not inherited features and likely emerge during continental break-up and oceanization phases instead.

\section{Cases of failed triple junctions}

We have calculated the vertical strain rates for the available stratigraphic columns from the rift-arms of three failed triple junctions (Figure 1). These are the Benue/Potiguar, South Australia, and the North Sea, representing three different cases of triple junctions: R-R-R followed by a breakup, R-R-F and breakup, and R-R-R with no breakup, respectively. Although not exhaustive, these known cases illustrate the evolution of continental rifts under a range of different conditions.

The calculated vertical strain rates quantify and illustrate the regional-scale evolution across the entire basins to support a synoptic synthesis. Water-loaded tectonic subsidence was calculated using backstripping method (Watts and Ryan, 1976), then interpolated using a cubic spline to calculate vertical strain rates following method in White (1994), while temperature-dependent density was neglected.

The first example of a failed triple junction occurs during the diverging South America and Africa plates. This divergence is associated with a "quadruple" junction (Figure 1A), where the Southern and Equatorial Atlantic intersect Benue and Potiguar continental rifts. 
104 Strain curves retrieved from the coastal basins along the passive rifted margins of the

105 Southern and Equatorial Atlantic show multiple episodic peaks corresponding to the recorded

106 Atlantic rifting phases (Nürnberg and Müller, 1991). Onshore NE-SW Potiguar rift, on the

107 South American side, evolved from 141 to 128 Myr (Lopes et al., 2018) with a recovered

108 strain rate value around $10^{-15} \mathrm{~s}^{-1}$. The rift associated with an erosional event, i.e., null in the

109 strain data at $125 \mathrm{Myr}$, concurrently with the onset of the Equatorial Atlantic Ocean

110 opening. At that stage, the rift-axis shifted to an E-W direction due to the South America

111 plate kinematics (Lopes et al., 2018), while the intra-continental NE-SW rift got abandoned.

112 The corresponding Anambra Basin in the southern trans-tensional Benue trough, part of the

113 West African Rift System (WARS), was nearly dormant during the separation of the two

114 continents, as indicated by low strain rates $<10^{-16} \mathrm{~s}^{-1}$. It got activated, associated with the

115 Santonian compressive folding event that causes basin depocenter shift, with a strain rate

116 peaks at $10^{-15} \mathrm{~s}^{-1}$ between $\sim 95$ and $85 \mathrm{Ma}$ before it faded (Wright 1981). The associated

117 volcanism was suggested to be a consequence of the unstable R-R-F junction's kinematics in

118 the region (Grant, 1971), while White and McKenzie (1989) proposed that far-field boundary

119 forces caused decompression melting above a hot spot as a cause of the flood basalts in the

120 region. Although St. Helena plume, near the junction, is suggested to contribute to the South

121 Atlantic opening, lower buoyancy flux suggests a lesser influence in the area (Sleep, 1990;

122 Wilson, 1992).

A second example is the magma-poor triple junction in Southeast Australia that evolved into successful plate margins (Meeuws et al., 2016). The separation between Australia and

126 Antarctica occurred along an R-R-F triple junction where the Bass Strait, and its associated

127 basins, preserve the record of a failed rift arm. Strain rate curves show a peak activity at 100-

12880 Myr with values over $\sim 10^{-15} \mathrm{~s}^{-1}$ in the Otway Basin and Bass Basin corresponding to the

129 eastward propagation of the rifting (Figure 1B). The transform Tasman Fracture Zone

130 developed 55-34 Myr later along the western margin of Tasmania (Gibson et al., 2011,

131 2012), influenced by the Moyston Fault Zone, a pre-existing buried lithospheric tectonic

132 boundary which separates the Proterozoic-Cambrian Delamerian Orogen from the

133 Phanerozoic Lachlan Fold Belt (Gibson et al. 2013). The development of this transform fault

134 is marked by a high strain rate of $\sim 10^{-15.5} \mathrm{~s}^{-1}$ in the western Bass Basin, while the Otway

135 Basin and East Bass Basin were quiescent (Brown et al., 2003). Although speculative,

136 tectonic drivers for developing the SE Australia triple junction likely involved the 
superposition of two far-field boundary forces as evident from the analysis of seafloor

138 spreading isochrons. These are, rift propagation from the west and the rotation from the northeast (Veevers and Li, 1991), and suggests that a plume was an unlikely influence on continental rifting (Meeuws et al., 2016).

The North Sea triple junction represents a multistage rift system developed within an 143 area of intersecting linear pre-existing basement weaknesses (Figure 1C). The rifting history

144 records complex shifts in the rift axis location and a significant rotation of the kinematic 145 velocity vector directions (Erratt et al. 1999). Strain rate curves from the major basins support 146 an episodic rifting regime with distinctive timing. Although, the evolution of the North Sea

147 rift associated with a near-central uplift attributed to a thermal anomaly, White and Latin 148 (1993) questioned the hotspot influence in the area, given that the amount of the basalt in the 149 central part is less than what a plume model predicts, while there is no record of a plume-tail.

150 Latin et al. (1990) suggested that the doming in the Central North Sea was short-lived and relatively localized.

Preceding examples illustrate the protracted episodic evolution of the three-rift arms of 154 divergent triple junctions that do not fit in a plume-driven model of triple junction formation.

155 This suggests that mature divergent triple junctions result from distinct rifting episodes 156 influenced by evolving boundary forces and internal heterogeneities. 

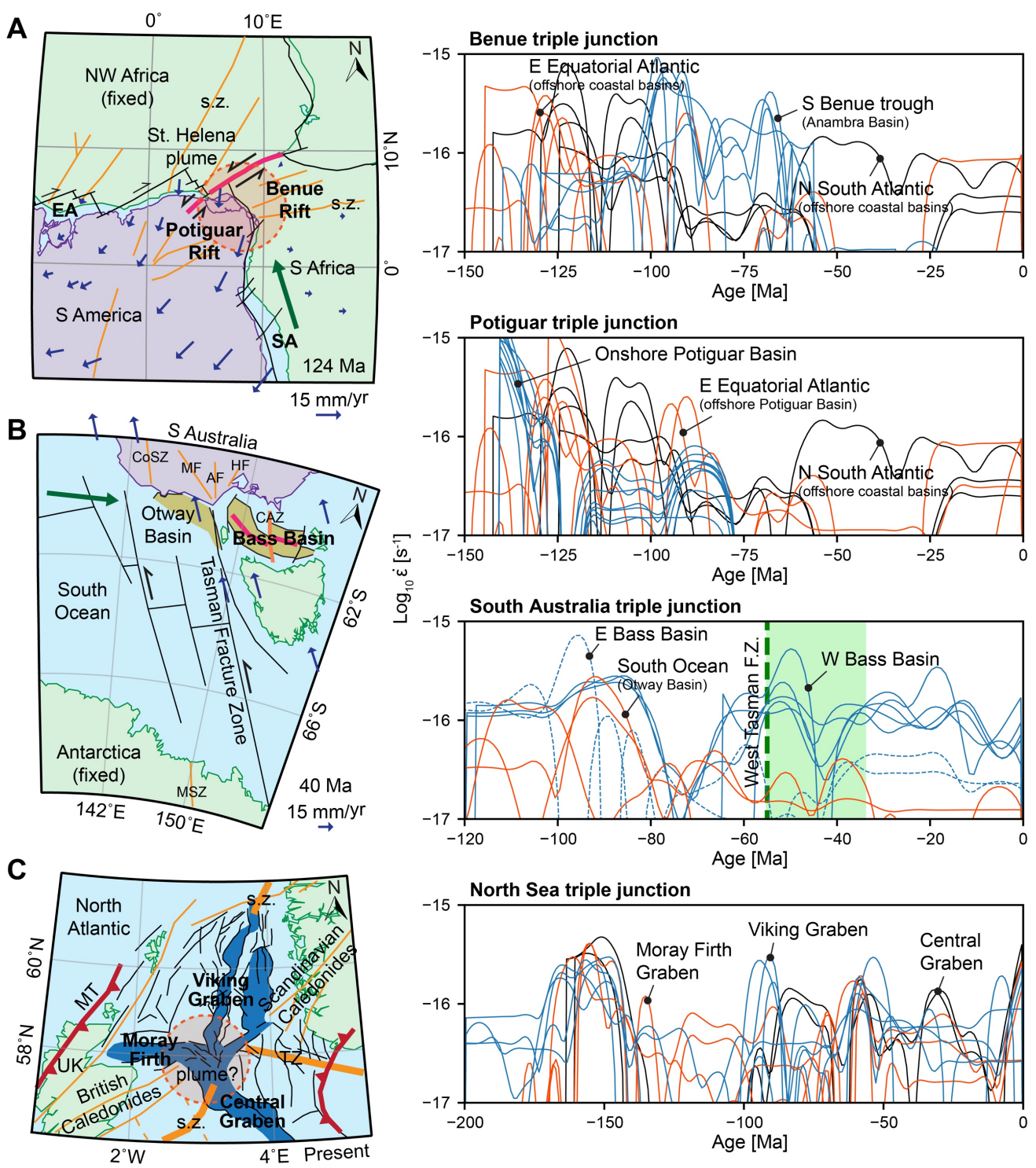

Figure 1. Left, paleogeographic reconstructions (Muller et al., 2016) using GPlate software with structural features annotated on top of some natural failed triple junctions. Right, corresponding calculated profiles of the vertical strain rate of each triple junction case. A,

161 Benue and Potiguar rift systems formed a quadruple junction with off-cantered plume, after

162 Wilson (1992); B, the magma-poor Otway-Bass-Tasman triple junction in Southern Australia

163 after Gibson et al. (2013). C, North Sea rifting system with a centred thermal anomaly

164 (plume?) after Erratt et al. (1999). EA, Equatorial Atlantic; SA, South Atlantic; s.z., shear 165 zone; CoSZ, Coorong Shear Zone; MF, Moyston Fault; AF, Avoca Fault; HF, Heathcote

166 Fault; CAZ, Chat Accommodation Zone; MSZ, Mertz Shear Zone; MT, Moine Thrust.

\section{Analog experiments and results}

Our laboratory experimental approach aims to simulate the initiation of active triple junctions and their subsequent structural evolution during divergence of two continents 
containing pre-existing heterogeneities and under different kinematic boundary conditions

172 (Khalil et al., 2020). The model lithosphere (Figure 2) consisted of a brittle upper crust,

173 viscous lower crust, and a high-viscosity lithospheric mantle. The model lithosphere floats on

174 a lower viscosity, higher density model asthenosphere, which provided isostatic support for

175 the deformation (for materials and scaling, refer to Khalil et al., 2020). The north-western

176 model boundary is fixed, while the north-eastern boundary is displaced at a controlled rate by

177 a linear actuator. The southern boundary is dragged passively. We systematically assessed the

178 role of far-field orthogonal and rotational extension in two different set-ups (Figure 2A and

179 B).

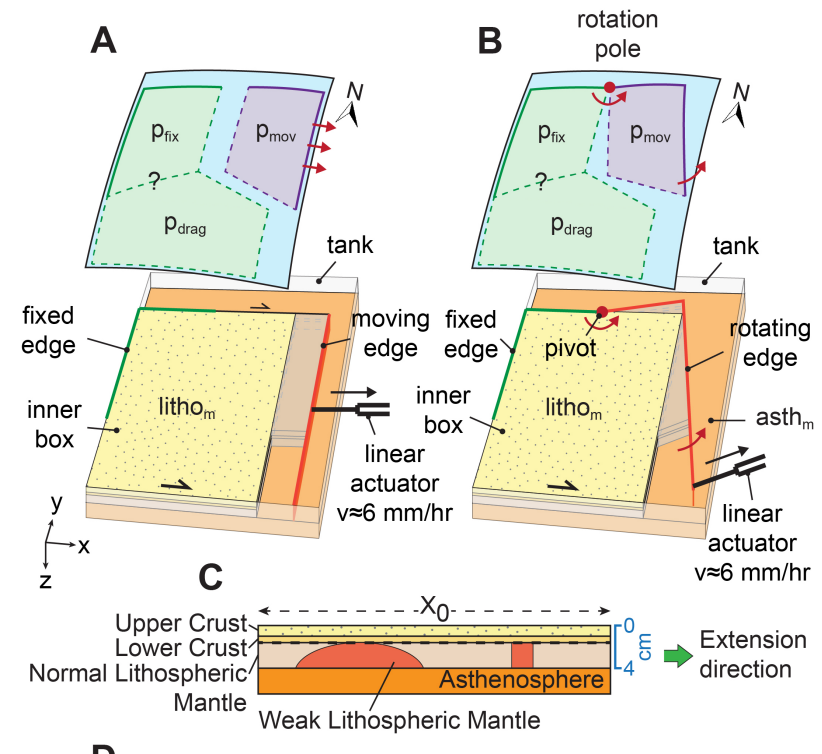

D

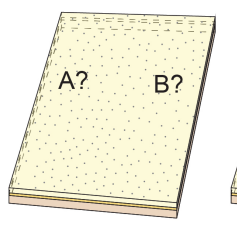

No junction

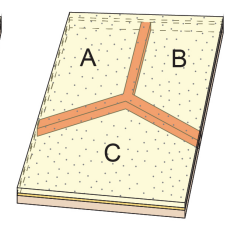

Triple junction

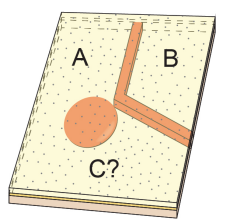

Plume-assisted double junction

Figure 2. 3D sketches of analog modeling set-ups under A, orthogonal and, B, rotational extension. C, cross-section showing the different model layers (after Khalil et al., 2020). p pix, modeled fixed plate. $p_{\text {mov }}$, moving plate. $p_{\text {drag }}$, passively dragged plate. litho $\mathrm{m}_{\mathrm{m}}$, model lithosphere. asth $_{\mathrm{m}}$, model asthenosphere. D, Isometric sketch showing the geometric configuration of the implemented model lithosphere weaknesses.

In a first set of reference experiments (Figure 3: Models 1 and 4), we applied orthogonal and rotational kinematic boundary conditions to model lithospheres containing no preimposed weaknesses. In the second set of experiments (Figure 3: Models 2 and 5), we 
simulated three pre-existing, linear weak lithospheric-scale heterogeneities at an angle of

$191120^{\circ}$ to each other, with an initial triple junction configuration. Finally, in a third set of

192 experiments (Figure 3: Models 3 and 6) two linear, pre-existing weaknesses, $120^{\circ}$ apart,

193 intersect a hemispherical weakness, representing a plume-related thermal perturbation.

A

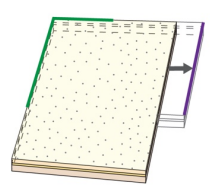

model 1

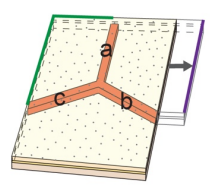

model 2

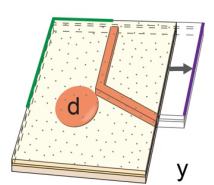

model 3 early
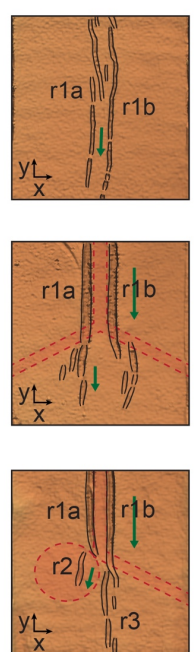

0 advanced
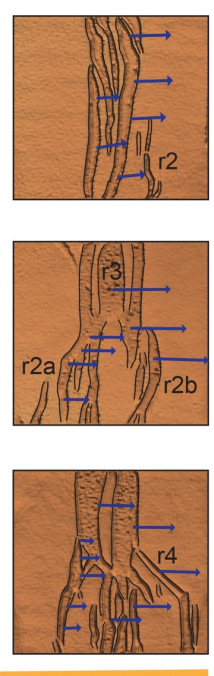

B

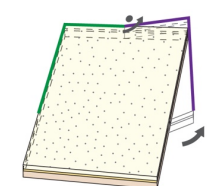

model 4

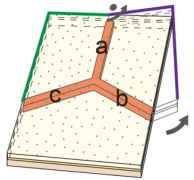

model 5

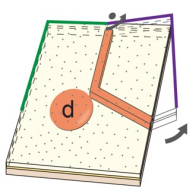

model 6
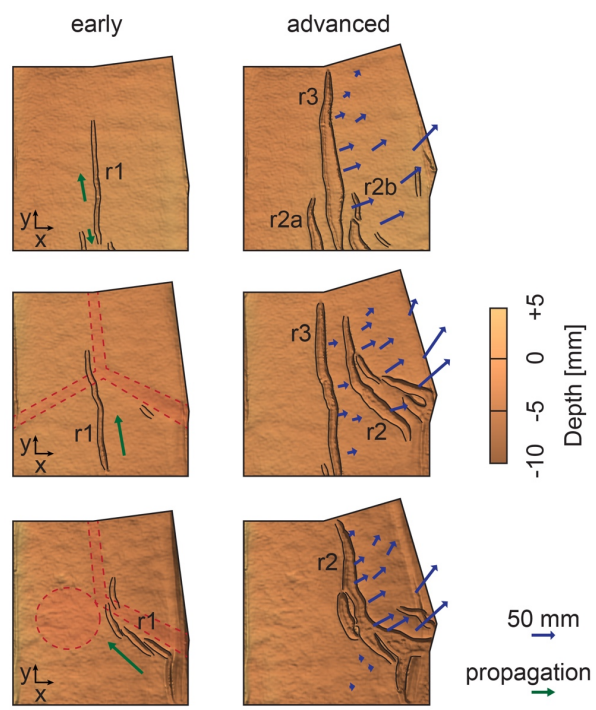

0

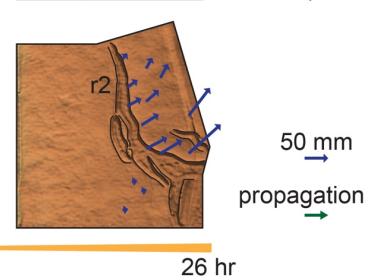

Figure 3. Analogue experiments and results. A, experiments under orthogonal extension; B, experiments under rotational extension. The first column represents the $3 \mathrm{D}$ geometric layout pre-existing weaknesses in the models; the second and third columns represent surface elevations of the early and late evolution stages. a-c, linear weaknesses. d, hemispherical weakness.

During orthogonal extension (Figure 3A), the model with no pre-existing weaknesses (Model 1) first formed two central parallel rifts (r1a, r1b), and a later rift in the south east (r2), all of which were perpendicular to the extension direction. In the model with three intersecting pre-existing linear heterogeneities (triple junction configuration; Model 2), two initial parallel rifts $(\mathrm{rla}, \mathrm{rlb})$ formed adjacent to the north-south trending pre-existing weakness. These rifts propagated southward and branched out to the southeast and southwest into several rift segments, but no triple-junction formed. At later stages, strain localized in a north central rift (r3) while the flanking rifts ( $\mathrm{rla}, \mathrm{r} 1 \mathrm{~b})$ were abandoned. With increased stretching, the central rift (r3) coalesced with the southern rift segments (r2a, r2b). The model

210 with two pre-existing linear heterogeneities that intersect a hemispherical weakness (Model

2113 ) formed several well-defined rift zones (r1a, r1b, r2, r3, r4). Above the hemispherical

212 weakness, the westernmost rift (r2) evolved with an orientation that was slightly non- 
orthogonal to the extension direction. This structure connected with the northern rift (r1a)

214 along a rotated intra-rift block. Later in the model evolution, the western rift was abandoned,

215 and strain localized in a newly active eastern rift ( $\mathrm{r} 4)$.

Experiments with rotational extension (Figure 3B) developed similar structures and no

218 triple junctions. The model with no pre-existing weaknesses (Model 4) developed initial rifts

$219(\mathrm{r} 1, \mathrm{r} 2 \mathrm{a}, \mathrm{r} 2 \mathrm{~b}, \mathrm{r} 3)$ in the model center that propagated towards the pole of rotation. In the model with three intersecting pre-existing linear heterogeneities (triple junction configuration; Model 5) formed a rift in the south (r1) that was not influenced by the preexisting weaknesses and was oriented near-orthogonal to the initial rotational extension direction. Further stretching showed progressive strain accumulation into newly formed rifts $(\mathrm{r} 2, \mathrm{r} 3)$ that are favorably oriented, i.e., low-oblique, with the evolving stretching directions while the precursor rifts became dormant, i.e., failed rifts. A triple junction did not form in this experiment. The model with two pre-existing linear heterogeneities that intersect a hemispherical weakness (Model 6) developed two consecutive rift segments (r1, r2) that were aligned with the linear weaknesses. The eastern rift segments coalesced, and well-defined shear zones developed parallel to the extension direction, but no triple junction formed.

Cumulative surface normal strain calculated for the reference model, under orthogonal and rotational extension, shows the development of a central deformed zone (Figure 4A and D). Under orthogonal extension, the model lithosphere with a pre-existing triple junction configuration show no concurrent active three-rifts, but consecutive, episodic rifts evolved (Figure 4B). This is evident from the consecutive strain peaks. Under rotational extension, the same model shows a shift in the strike of the rift-axis towards the updated extensional directions and a consequent rift abandonment (Figure 4E). The implementation of a hemispherical weakness (models 3 and 6) shows that, under orthogonal extension (Figure 4C), distributive rifts develop with different timeframes while, under the rotational extension (Figure 4F), the hemispherical weakness existence contributes to the lithosphere weakening and favors two-arm rift configuration. 

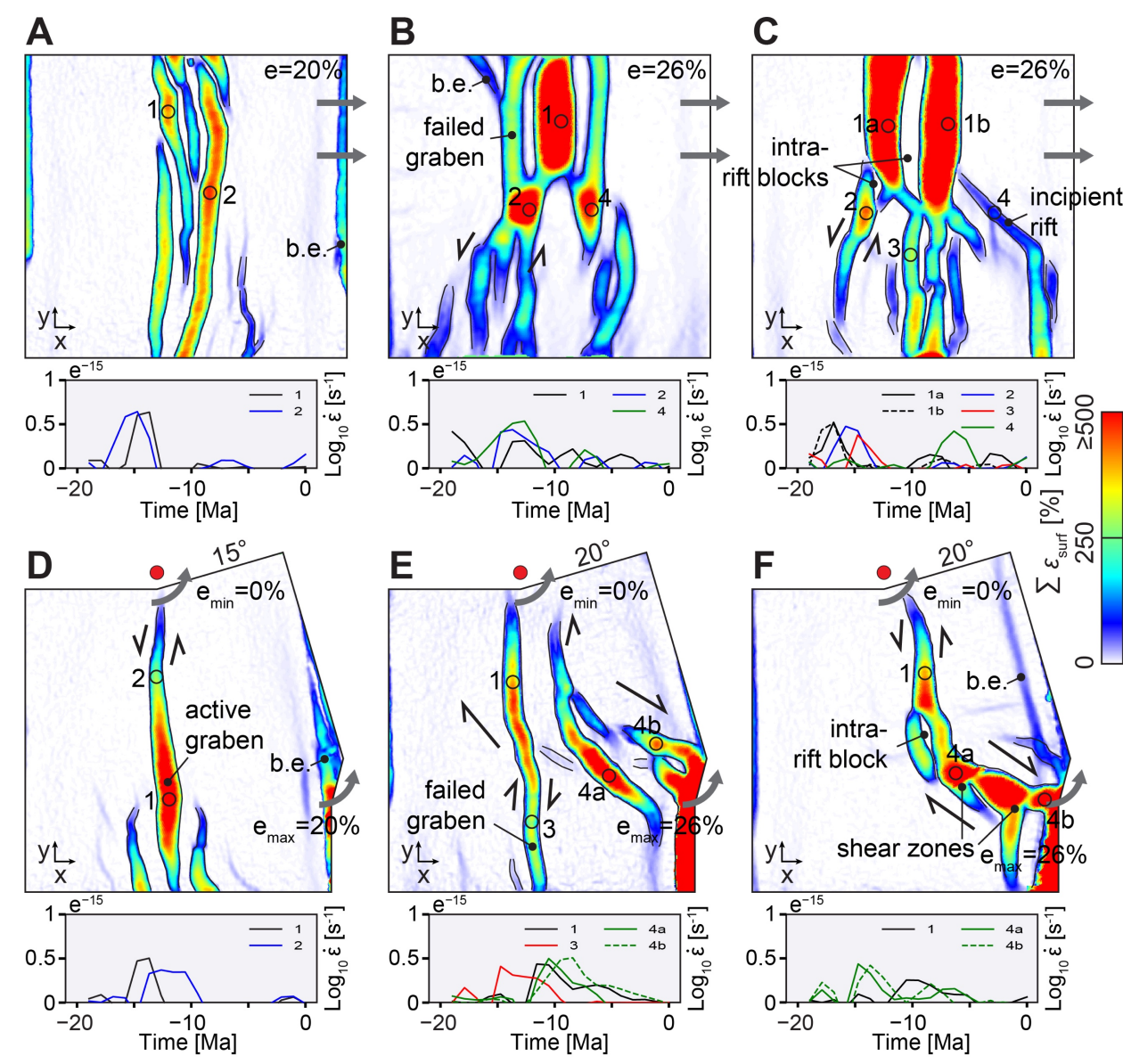

244 Figure 4. Cumulative surface normal strain in the experiments. A-C, models with orthogonal extension. D-F, models with rotational extension. A and D models contain no pre-existing weaknesses; B and E models with 3 pre-existing linear weaknesses with a triple junction configuration; $\mathrm{C}$ and $\mathrm{F}$ models with 2 pre-existing linear weaknesses, 120 apart intersecting a hemispherical weakness, simulating a mantle plume head.

\section{Discussion and Conclusions}

Observations from well-studied triple junctions and analog modeling strongly suggest that divergent triple junctions are result of episodic continental rifting phases with various timeframes. Thus, oceanic triple junctions are unlikely inherited from a single-phase continental rifting.

The boundary forces vary in magnitude and reorient continuously, ranging from orthogonal to non-orthogonal to rotational (Brune et al., 2014; Bellahsen et al., 2005). For example, in the Afar region, the separation of Arabia and Africa was influenced by far-field tectonics, with the opening of the Red Sea and the Gulf of Aden at circa 30-25 Ma, as a result of the rotational far-field forces acting on Arabia (Bellahsen et al. 2005; Khalil et al., 2020).

260 The third active arm, i.e., the Main Ethiopian Rift, developed later at circa $11 \mathrm{Ma}$ (Wolfenden 
et al. 2004). The kinematic rotational boundary condition control rift propagation mechanisms and rift geometries.

Rheological heterogeneities, including the thermal and buoyancy effects of the mantle plumes, localize strain and consequently influence where and how the lithosphere deforms differently under different boundary conditions (Brune, 2014; Molnar et al., 2017; Khalil et al., 2020). Ultimately, they affect the tectonic plate kinematics and strain distribution.

Although we implemented pre-existing linear weaknesses with a triple junction morphology (Models 2 and 5), triple junctions did not evolve in either orthogonal or rotational rifting experiments (Khalil et al., 2020). Instead, either a wide deformation zone or consecutive rifts developed during orthogonal or rotational extensions, respectively. The experiments suggest that a two-arm rift configuration is more likely to reach the oceanization stage due to favorable strain localization to the reoriented extension directions, i.e., rotational boundary conditions while preceding rifts got abandoned. Rift abandonment is observed in Model 5, while Model 6 exhibits a two-arm rift akin to the Red Sea-Gulf of Aden rifting (Khalil et al., 2020). These observations agree with comparable numerical models in which the success of a rift-arm is based on its favorable strike orientation to the extension direction (Heine and Brune 2014).

Structures must rearrange accordingly during the long-term evolution of divergent triple junctions. Re-orientation of rifts and the consequent strain jump can be explained as an energy minimization, in which constant deformation rates applied by the boundary conditions imply that the integral of the strain rate, i.e., the dissipation, inside the model must be equal and constant. Thus, the total dissipation integrated on active rifts does not change and, as new rifts form, the deformation in old, developed rifts must cease to keep the dissipation constant.

Even though a triple junction configuration is postulated to be formed due to the impingement of a mantle plume at the base of the lithosphere (Burke and Dewey, 1973), experimental work has shown that it cannot reach the continental breakup stage without the aid of bi-directional extension (Koptev et al., 2015). Our implementation of a hemispeheric weakness that simulates a mantle plume (Models 3 and 6) shows that the effect of the plume head favors distributed strain under orthogonal extension, while under rotational extension, it 
294 favors the strain localization in the neighboring double junction rifting (Bellahsen et al., 2003; Khalil et al., 2020).

We hypothesize that successful triple junctions are the inheritance of multiple and distinct continental rifting phases, in which the evolution is complex and involved multiple episodes of extension, thermal subsidence, and shifting depocenters. The role of the plume was to locally weaken the lithosphere and trigger initial rifting rather than the continental breakup itself.

302

\section{Acknowledgements}

304 We thank Anindita Samsu and Nicolas Molnar for advice and assistance in the Geodynamic Modeling Laboratory at Monash University.

\section{References}

Bellahsen, N., \& Daniel, J. M. (2005). Fault reactivation control on normal fault growth: an experimental study. Journal of Structural Geology, 27(4), 769-780.

Bellahsen, N., Fournier, M., d'Acremont, E., Leroy, S., \& Daniel, J. M. (2006). Fault reactivation and rift localization: Northeastern Gulf of Aden margin. Tectonics, 25(1).

Bellahsen, Nicolas, and Jean Marc Daniel. "Fault reactivation control on normal fault growth: an experimental study." Journal of Structural Geology 27, no. 4 (2005): 769-780.

Brown, B. J., Muller, R. D., Gaina, C., Struckmeyer, H. I. M., Stagg, H. M. J., \& Symonds, P. A. (2003). Formation and evolution of Australian passive margins: Implications for locating the boundary between continental and oceanic crust. SPECIAL PAPERSGEOLOGICAL SOCIETY OF AMERICA, 223-244.

Brune, S. (2014). Evolution of stress and fault patterns in oblique rift systems: 3-D numerical lithospheric-scale experiments from rift to breakup. Geochemistry, Geophysics, Geosystems, 15(8), 3392-3415.

Brune, S., Heine, C., Pérez-Gussinyé, M., \& Sobolev, S. V. (2014). Rift migration explains continental margin asymmetry and crustal hyper-extension. Nature communications, 5(1), 1-9.

Brune, S., Heine, C., Pérez-Gussinyé, M., \& Sobolev, S. V. (2014). Rift migration explains continental margin asymmetry and crustal hyper-extension. Nature communications, 5(1), 1-9. 
Burke, K., \& Dewey, J. F. (1973). Plume-generated triple junctions: key indicators in applying plate tectonics to old rocks. The Journal of Geology, 81(4), 406-433.

Burke, K., \& Dewey, J. F. (1973). Plume-generated triple junctions: key indicators in applying plate tectonics to old rocks. The Journal of Geology, 81(4), 406-433.

Burov, E., \& Gerya, T. (2014). Asymmetric three-dimensional topography over mantle plumes. Nature, 513(7516), 85-89.

Davies, R., Valentine, A. P., Kramer, S. C., Rawlinson, N., Hoggard, M., Eakin, C. M., \& Wilson, C. R. (2019, December). Constraining Earth's Multi-scale Topographic Response to Global Mantle Flow. In AGU Fall Meeting Abstracts (Vol. 2019, pp. DI33B-0017).

Erratt, D., Thomas, G. M., \& Wall, G. R. T. (1999, January). The evolution of the central North Sea Rift. In Geological society, london, petroleum geology conference series (Vol. 5, No. 1, pp. 63-82). Geological Society of London.

Erratt, D., Thomas, G. M., \& Wall, G. R. T. (1999, January). The evolution of the central North Sea Rift. In Geological society, london, petroleum geology conference series (Vol. 5, No. 1, pp. 63-82). Geological Society of London.

Gibson, G. M., Morse, M. P., Ireland, T. R., \& Nayak, G. K. (2011). Arc-continent collision and orogenesis in western Tasmanides: insights from reactivated basement structures and formation of an ocean-continent transform boundary off western Tasmania. Gondwana Research, 19(3), 608-627.

Gibson, G. M., Henson, P. A., Neumann, N. L., Southgate, P. N., \& Hutton, L. J. (2012). Paleoproterozoic-earliest Mesoproterozoic basin evolution in the Mount Isa region, northern Australia and implications for reconstructions of the Nuna and Rodinia supercontinents. Episodes, 35(1), 131-141.

Gibson, G. M., Totterdell, J. M., White, L. T., Mitchell, C. H., Stacey, A. R., Morse, M. P., \& Whitaker, A. (2013). Pre-existing basement structure and its influence on continental rifting and fracture zone development along Australia's southern rifted margin. Journal of the Geological Society, 170(2), 365-377.

Gordon, R. G. (1995). Plate motions, crustal and lithospheric mobility, and paleomagnetism: Prospective viewpoint. Journal of Geophysical Research: Solid Earth, 100(B12), 24367-24392.

Grant, N. K. (1971). South Atlantic, Benue Trough, and Gulf of Guinea Cretaceous Triple Junction. Geological Society of America Bulletin, 82(8), 2295-2298. 
Heine, C., \& Brune, S. (2014). Oblique rifting of the Equatorial Atlantic: why there is no Saharan Atlantic Ocean. Geology, 42(3), 211-214.

$$
\text { Khalil, H. M., Capitanio, F. A., Betts, P. G., \& Cruden, A. R. (2020). 3-D Analog }
$$
Modeling Constraints on Rifting in the Afar Region. Tectonics, 39(10), e2020TC006339.

Koopmann, H., Brune, S., Franke, D., \& Breuer, S. (2014). Linking rift propagation barriers to excess magmatism at volcanic rifted margins. Geology, 42(12), 1071-1074.

Koopmann, H., Brune, S., Franke, D., \& Breuer, S. (2014). Linking rift propagation barriers to excess magmatism at volcanic rifted margins. Geology, 42(12), 1071-1074.

Koptev, A., Calais, E., Burov, E., Leroy, S., \& Gerya, T. (2015). Dual continental rift systems generated by plume-lithosphere interaction. Nature Geoscience, 8(5), 388-392.

Koptev, A., Calais, E., Burov, E., Leroy, S., \& Gerya, T. (2015). Dual continental rift systems generated by plume-lithosphere interaction. Nature Geoscience, 8(5), 388-392.

Latin, D. M., Dixon, J. E., \& Fitton, J. G. (1990). Rift-related magmatism in the North Sea Basin. In Tectonic evolution of the North Sea rifts (pp. 101-144).

Lopes, J. A., de Castro, D. L., \& Bertotti, G. (2018). Quantitative analysis of the tectonic subsidence in the Potiguar Basin (NE Brazil). Journal of Geodynamics, 117, 60-74.

McKenzie, D. P., \& Morgan, W. J. (1969). Evolution of triple junctions. Nature, 224(5215), 125-133.

Meeuws, F. J., Holford, S. P., Foden, J. D., \& Schofield, N. (2016). Distribution, chronology and causes of Cretaceous-Cenozoic magmatism along the magma-poor rifted southern Australian margin: Links between mantle melting and basin formation. Marine and Petroleum Geology, 73, 271-298.

Molnar, N. E., Cruden, A. R., \& Betts, P. G. (2017). Interactions between propagating rotational rifts and linear rheological heterogeneities: Insights from three-dimensional laboratory experiments. Tectonics, 36(3), 420-443.

Molnar, N. E., Cruden, A. R., \& Betts, P. G. (2018). Unzipping continents and the birth of microcontinents. Geology, 46(5), 451-454.

Moucha, R., \& Forte, A. M. (2011). Changes in African topography driven by mantle convection. Nature Geoscience, 4(10), 707-712.

Müller, R. D., Seton, M., Zahirovic, S., Williams, S. E., Matthews, K. J., Wright, N. M., ... \& Cannon, J. (2016). Ocean basin evolution and global-scale plate reorganization events since Pangea breakup. Annual Review of Earth and Planetary Sciences, 44, 107-138. 
Nürnberg, D., \& Müller, R. D. (1991). The tectonic evolution of the South Atlantic from Late Jurassic to present. Tectonophysics, 191(1-2), 27-53.

Peace, A., Foulger, G., Schiffer, C., \& McCaffrey, K. (2017). Evolution of Labrador

395

396

397

398

399

400

401

402

403

404

405

406

407

408

409

410

411

412

413

414

415

416

417

418

419

420

421

422

423

424

Sea-Baffin Bay: plate or plume processes?. Geoscience Canada: Journal of the Geological Association of Canada/Geoscience Canada: journal de l'Association Géologique du Canada, 44(3), 91-102.

Sleep, N. H. (1990). Hotspots and mantle plumes: Some phenomenology. Journal of Geophysical Research: Solid Earth, 95(B5), 6715-6736.

Veevers, J. J., \& Li, Z. X. (1991). Review of seafloor spreading around Australia. II. Marine magnetic anomaly modelling. Australian Journal of Earth Sciences, 38(4), 391-408.

Watts, A. B., \& Ryan, W. B. F. (1976). Flexure of the lithosphere and continental margin basins. In Developments in Geotectonics (Vol. 12, pp. 25-44). Elsevier.

White, N. (1994). An inverse method for determining lithospheric strain rate variation on geological timescales. Earth and Planetary Science Letters, 122(3-4), 351-371.

White, N., \& Latin, D. (1993). Subsidence analyses from the North Sea 'triplejunction'. Journal of the Geological Society, 150(3), 473-488.

White, R., \& McKenzie, D. (1989). Magmatism at rift zones: the generation of volcanic continental margins and flood basalts. Journal of Geophysical Research: Solid Earth, 94(B6), 7685-7729.

Wilson, M. (1992). Magmatism and continental rifting during the opening of the South Atlantic Ocean: a consequence of Lower Cretaceous super-plume activity?. Geological Society, London, Special Publications, 68(1), 241-255.

Wolfenden, E., Ebinger, C., Yirgu, G., Deino, A., \& Ayalew, D. (2004). Evolution of the northern Main Ethiopian rift: birth of a triple junction. Earth and Planetary Science Letters, 224(1-2), 213-228.

Wolfenden, E., Ebinger, C., Yirgu, G., Renne, P. R., \& Kelley, S. P. (2005). Evolution of a volcanic rifted margin: Southern Red Sea, Ethiopia. Geological Society of America Bulletin, 117(7-8), 846-864. 


\section{Supplementary information 1}

\section{Backstripping}

Backstripping technique (Watts and Ryan,1976; Steckler and Watts, 1978) is a straightforward application to quantify the isostatic response of a stratigraphic section in a sedimentary basin (Muller et al, 2018). The aim of the backstripping is to retrieve the geohistory, e.g., subsidence and uplift, of the sedimentary basin as a function of time (Van Hinte, 1978; Fig. 3.1).

433

We used the mud log records, of the studied wells, from literature, to obtain the present-day thickness of the different stratigraphic units, their lithologies, their petrophysical properties, and the age of the different horizons. Following the approach of e.g. Steckler and Watts (1978), Watts (1981), Alan et al (1998), and Muller et al (2018), we started by decompacting each sedimentary stratum to the time where it deposited using the following relationships:

$$
\emptyset_{z}=\emptyset_{0}^{\left(-\frac{z}{c}\right)}
$$

Where $\varnothing_{0}$ is the surface porosity of the sedimentary unit, $\varnothing_{\mathrm{z}}$ is the porosity at depth $z$, and $c$ is the porosity coefficient. The values of $\varnothing_{0}$ and $c$ depend on the lithology of each sedimentary unit and summarize in Table $1 . d_{0}$ and $d_{\mathrm{n}}$ are the surface position of the sedimentary unit, during its depositional time, and the burial depth of the unit, after time $\mathrm{n}$, respectively. While $t_{0}$ and $t_{\mathrm{n}}$ represent the original unit thickness, during its depositional time, and the compacted thickness, when the unit is at depth $d_{\mathrm{n}}$, respectively. The term $\left(1-\emptyset_{\mathrm{z}}\right)$ represents the incompressible component of the sedimentary unit, i.e., the volume of the grains, assuming a no cementation or late-stage diagenesis.

To do so, we removed the overburden sedimentary load above each unit and restored its decompacted thickness by solving numerically for $t_{0}$ :

$$
t_{0}=t_{n}-v w_{n}+v w_{0}
$$

where $v w_{0}$ is a function of $t_{0}$ and represents the original pore volume when the sedimentary unit was at the surface, while $v w_{\mathrm{n}}$ represents the pore volume when the sedimentary unit was at depth $d_{\mathrm{n}}$.

Consequently, we corrected the thicknesses of the underlying units and calculated the total subsidence as a sum of the units' thicknesses at each time n. Then we separated the tectonic subsidence component from the total subsidence using the following equation: 


$$
z_{n}=s_{n} *\left(\frac{\rho_{m}-\rho_{b}}{\rho_{m}-\rho_{w}}\right)+w_{d}-s_{l} *\left(\frac{\rho_{m}}{\rho_{m}-\rho_{w}}\right)
$$

Where $\rho_{\mathrm{m}}$ is the density of the mantle $=3300 \mathrm{~kg} / \mathrm{m}^{3}, \rho_{\mathrm{b}}$ is the retrieved bulk density of the unit after the decompaction correction, $\rho_{\mathrm{w}}$ is the water density $=1000 \mathrm{~kg} / \mathrm{m}^{3}, \mathrm{~s}_{\mathrm{n}}$ is the total subsidence of the basin at time $\mathrm{n}, \mathrm{w}_{\mathrm{d}}$ is the paleowater depth, $\mathrm{s}_{1}$ is the sea level change.

We tracked and plotted the total and tectonic subsidence with time as shown in

481

482

483

484

485

486

487

488

489

490

491

492

493

\begin{tabular}{|l|c|c|c|}
\hline Lithology & $\begin{array}{c}\text { Density } \\
\mathrm{kg} / \mathrm{m}^{3}\end{array}$ & $\begin{array}{c}\text { Surface } \\
\text { porosity } \\
\% / 100\end{array}$ & $\begin{array}{c}\text { Porosity } \\
\text { coefficient } \\
\mathrm{m}^{-1}\end{array}$ \\
\hline sand & 2650 & 0.49 & 0.00026998 \\
\hline shale & 2720 & 0.63 & 0.0005102 \\
\hline dolomite & 2870 & 0.38 & 0.00050352 \\
\hline limestone & 2850 & 0.51 & 0.00022002 \\
\hline Anhydrite & 2950 & $1 \mathrm{E}-10$ & 0.1 \\
\hline Basalt & 2700 & 0.2 & 0.0002 \\
\hline shaly sand & 2680 & 0.56 & 0.00039002 \\
\hline silt & 2661 & 0.76 & 0.00091659 \\
\hline carbonate sand & 2710 & 0.48 & 0.00025063 \\
\hline conglomerate & 2600 & 0.5 & 0.0003 \\
\hline clay & 2735 & 0.76 & 0.00079872 \\
\hline
\end{tabular}

Table 1 - Porosity-depth relationships for common lithologies. Values are from Müller et al., 2018 .

\section{References:}

Watts, A.B.; Ryan, W.B.F. (1976). "Flexure of the lithosphere and continental margin basins". Tectonophysics. 36 (1-3): 25-44

Watts, A. B. (1981). The US Atlantic continental margin: subsidence history, crustal structure and thermal evolution.

van Hinte, J. E.. 1978. Geohistory analysis-application of micropalaeontology in exploration geology, AAPG Bull., 62,

$201-222$. 
495 flexural backstripping of extensional basins: the need for a sideways glance" Petroleum 496 Geoscience 4:327-338

497 Steckler, M.S. and Watts, A.B (1978). "Subsidence of the Atlantic-type continental 498 margin off New York" Elsevier 41:1-13

499 Müller, R. D., Cannon, J., Williams, S., \& Dutkiewicz, A. (2018). PyBacktrack 1.0: A

500 tool for reconstructing paleobathymetry on oceanic and continental crust. Geochemistry, 501 Geophysics, Geosystems, 19(6), 1898-1909.

502

503

504

505

506

507

508

509

510

511

512

513

514

515

516

517

518

519

520

521

522

523

524

525

526

527

528

529

530

531

532

533

534

535

536 


\section{Supplementary information 2}

\section{Studied localities}

543
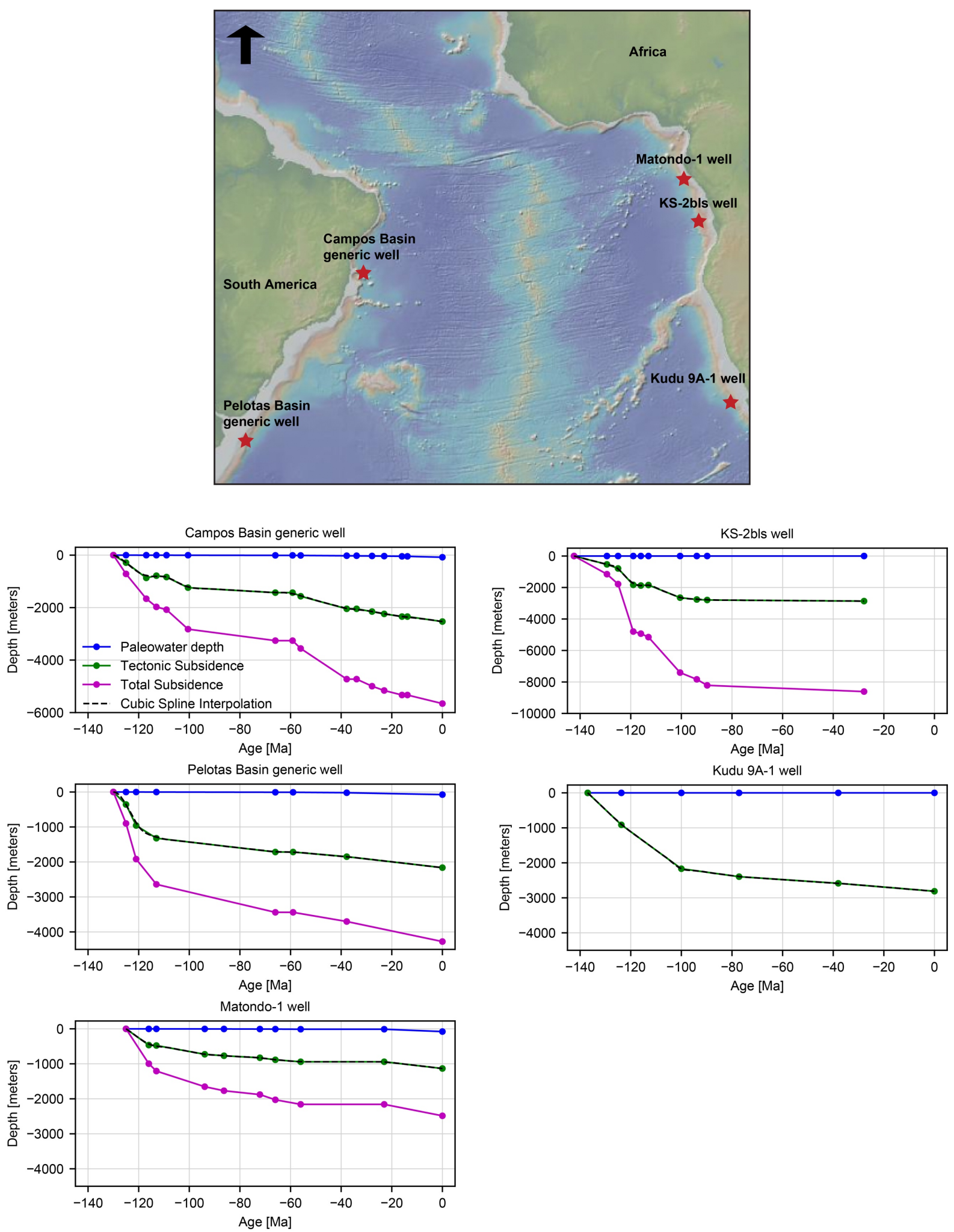

546 Figure S1 - location and subsidence data of the studied wells in the Southern Atlantic. 

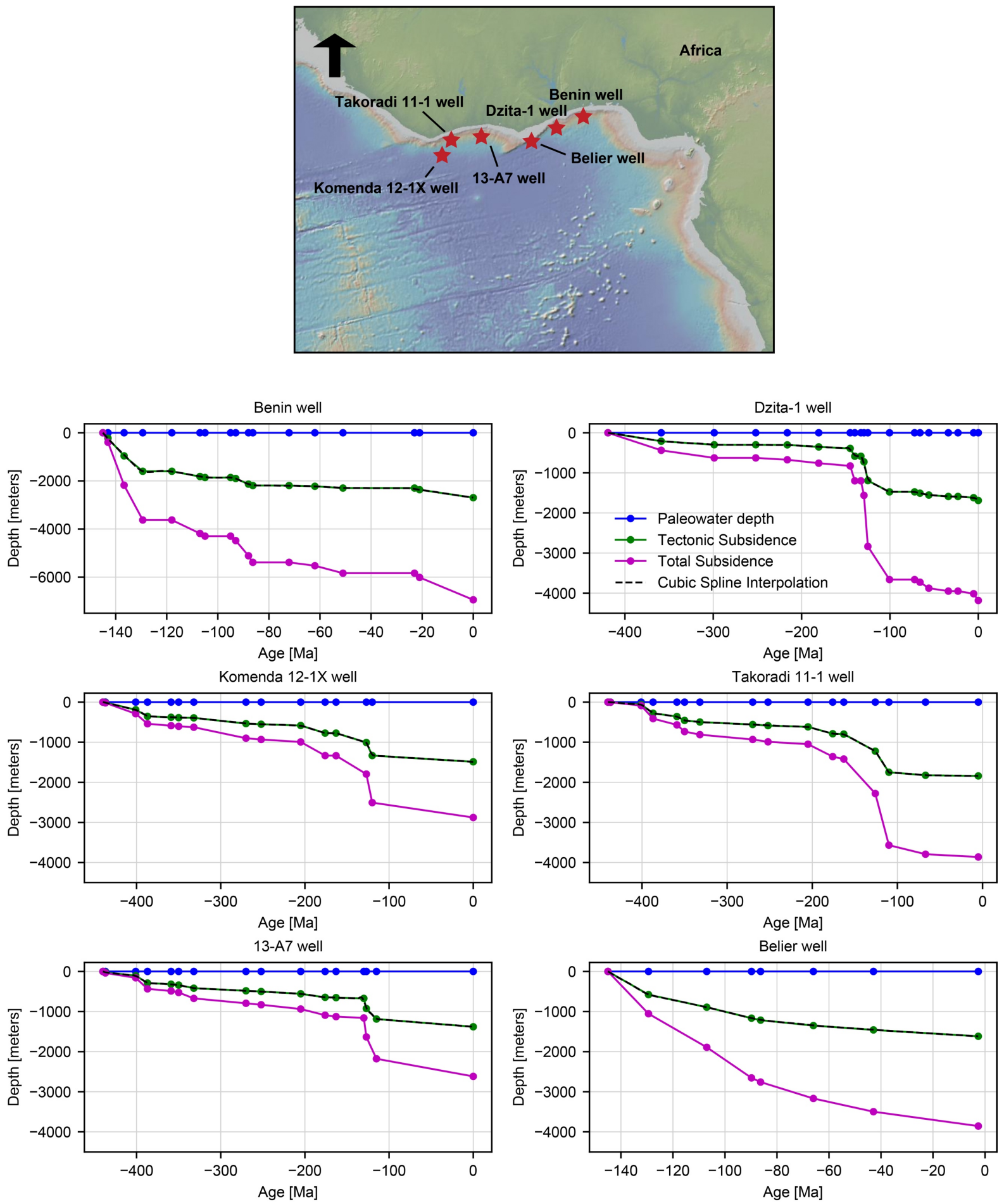

Figure S2 - location and subsidence data of the studied wells in the Equatorial Atlantic. 

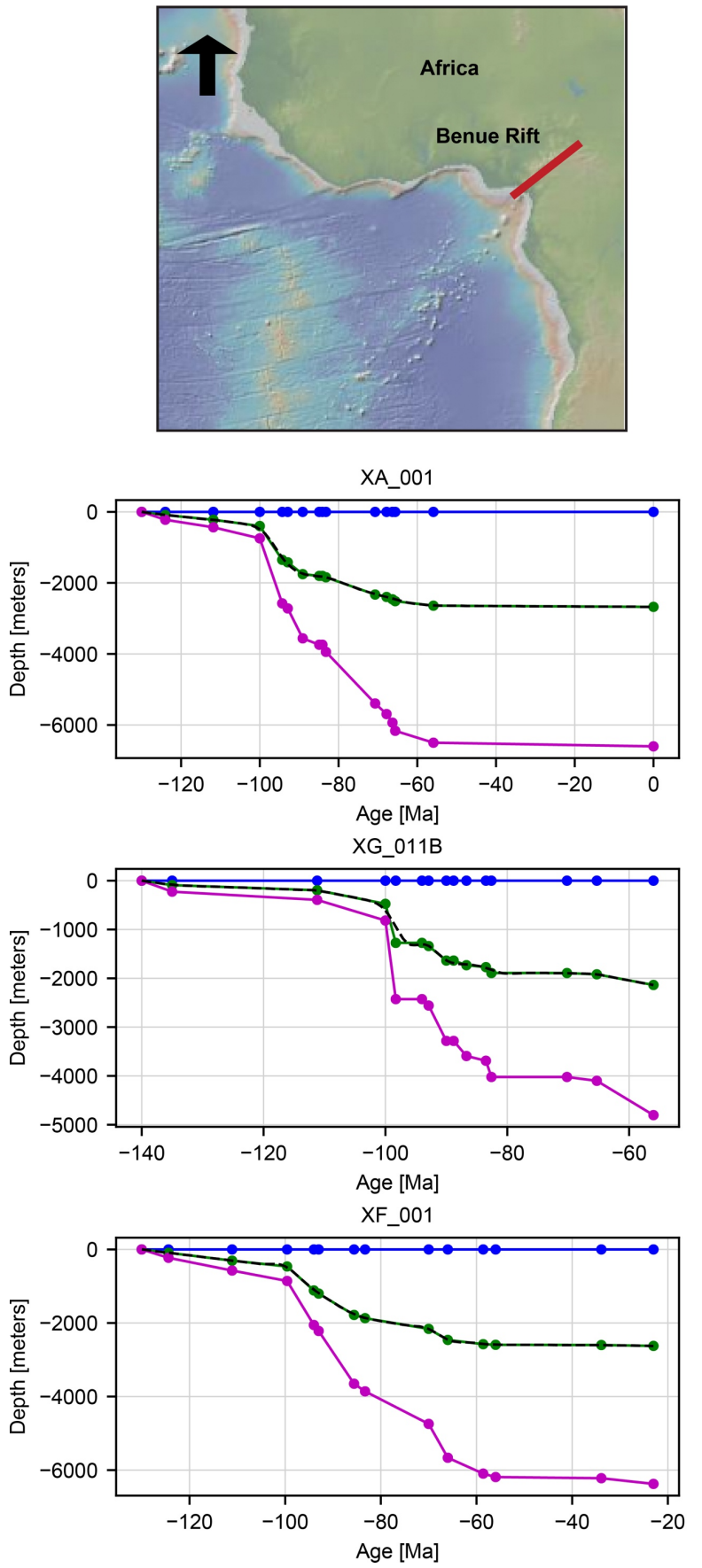

Figure S3 - location and subsidence data of the studied wells in the Benue trough.
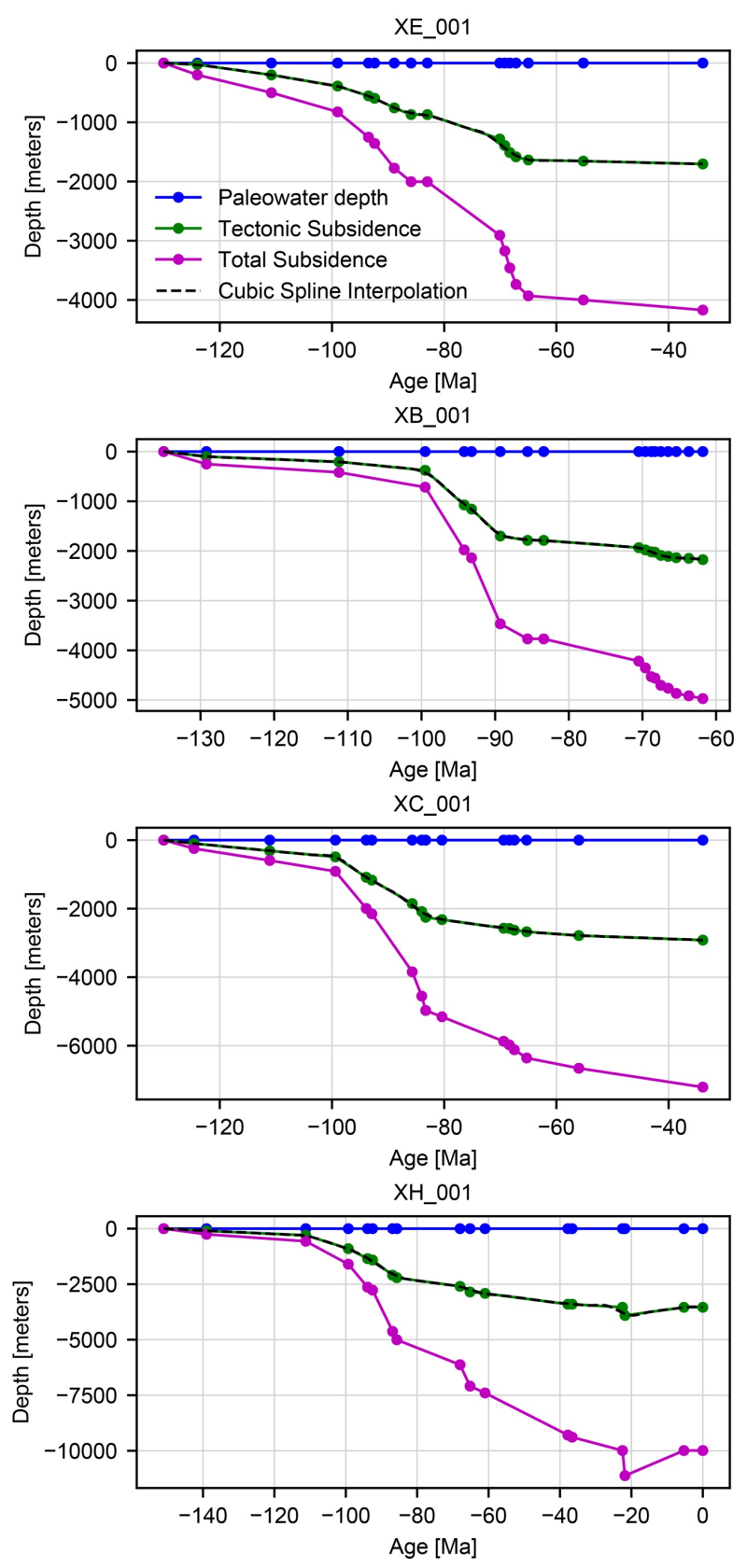

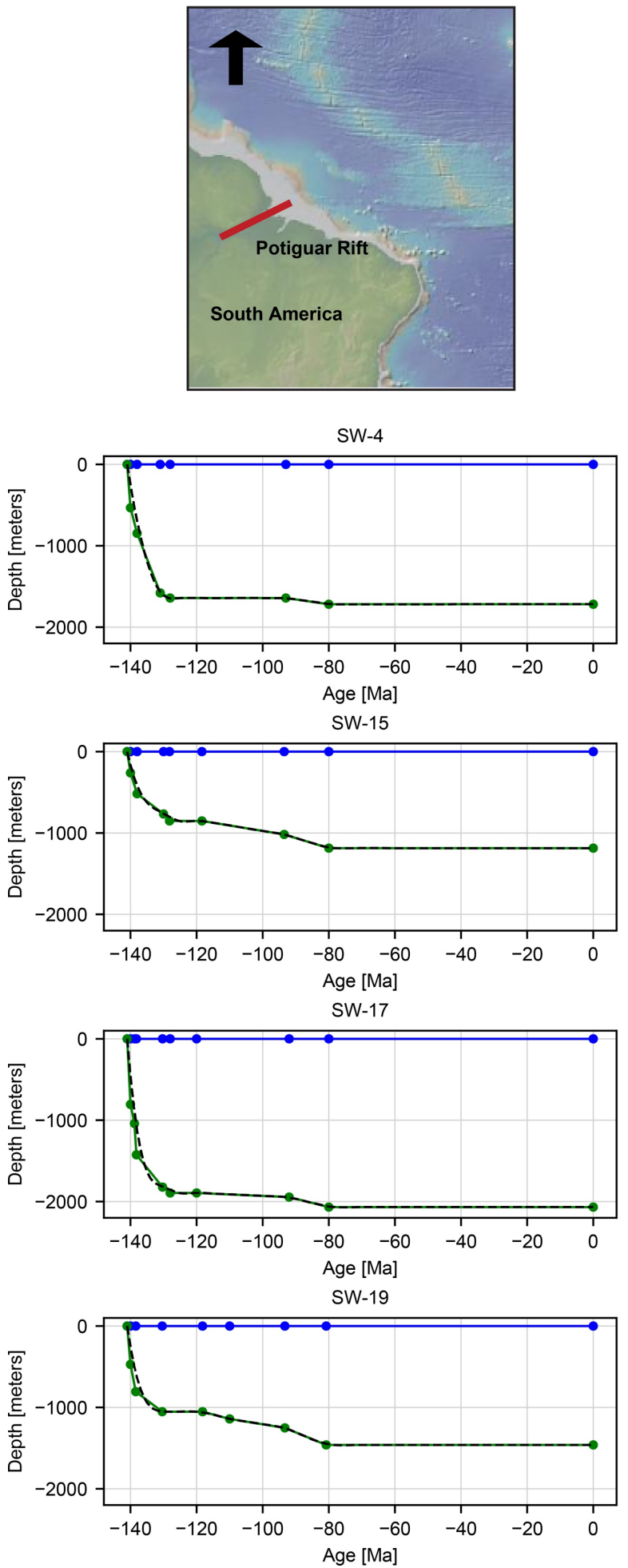
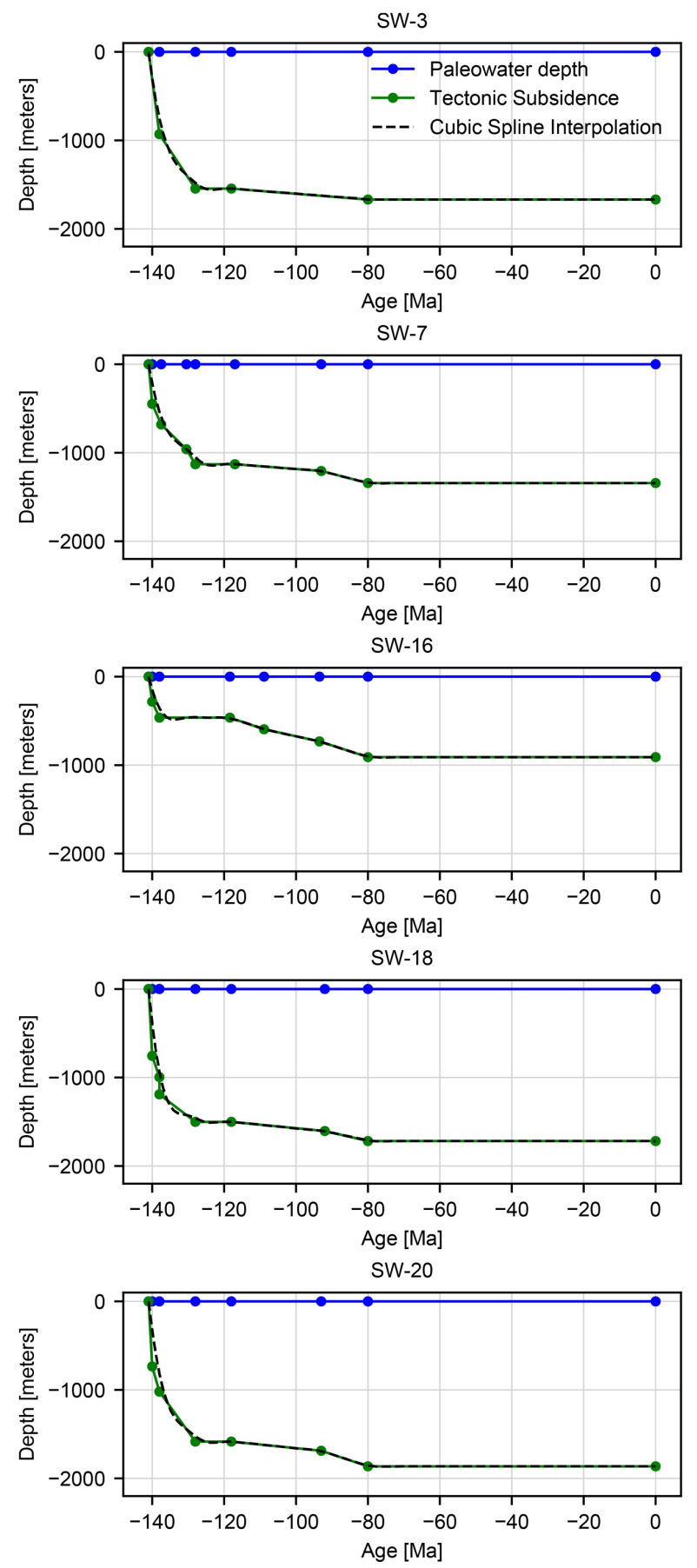

Figure S4 - location and subsidence data of the studied wells in the Potiguar Rift. 

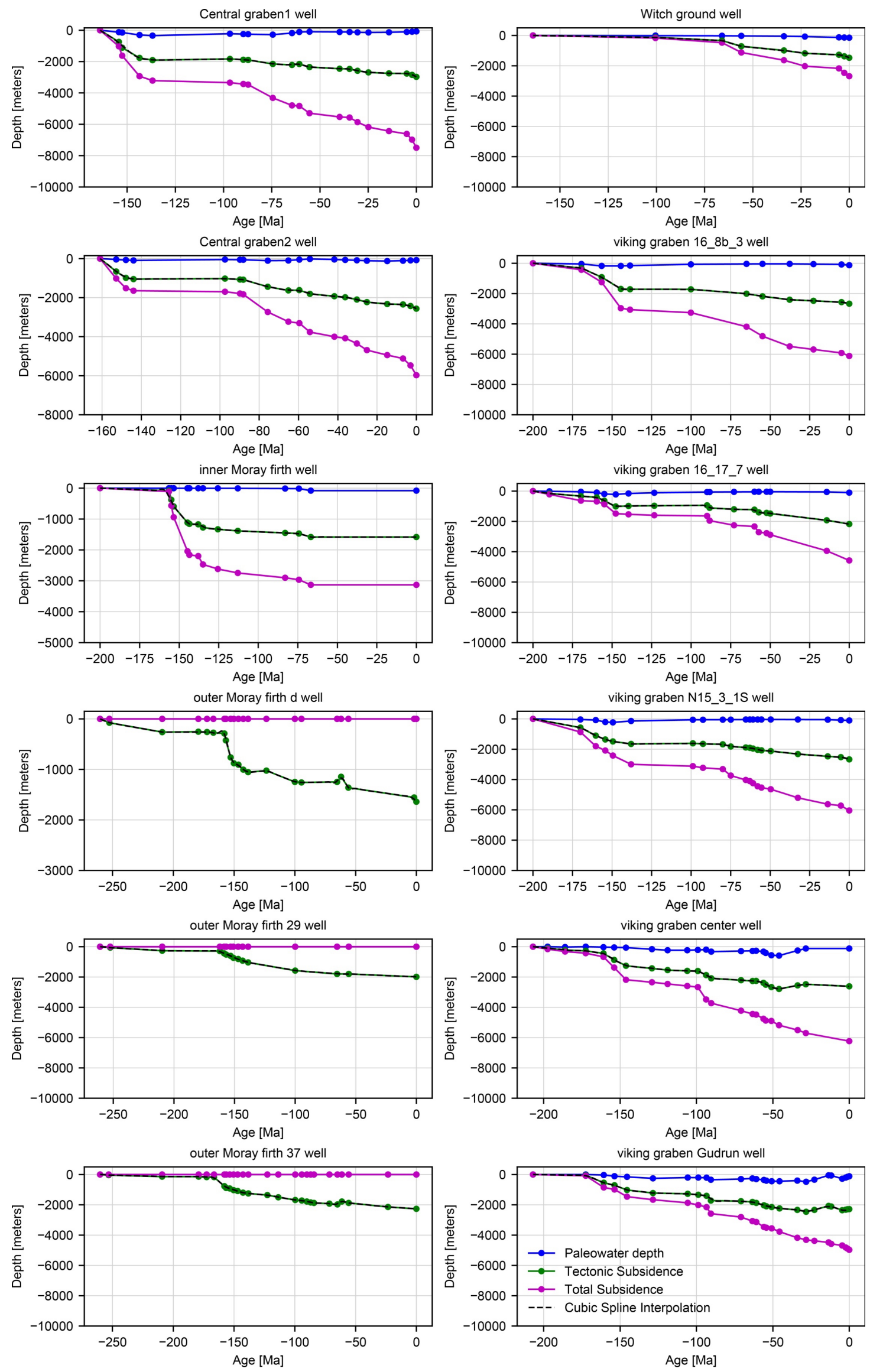

582 Figure S5 -Subsidence data of the studied wells in the North Sea. 

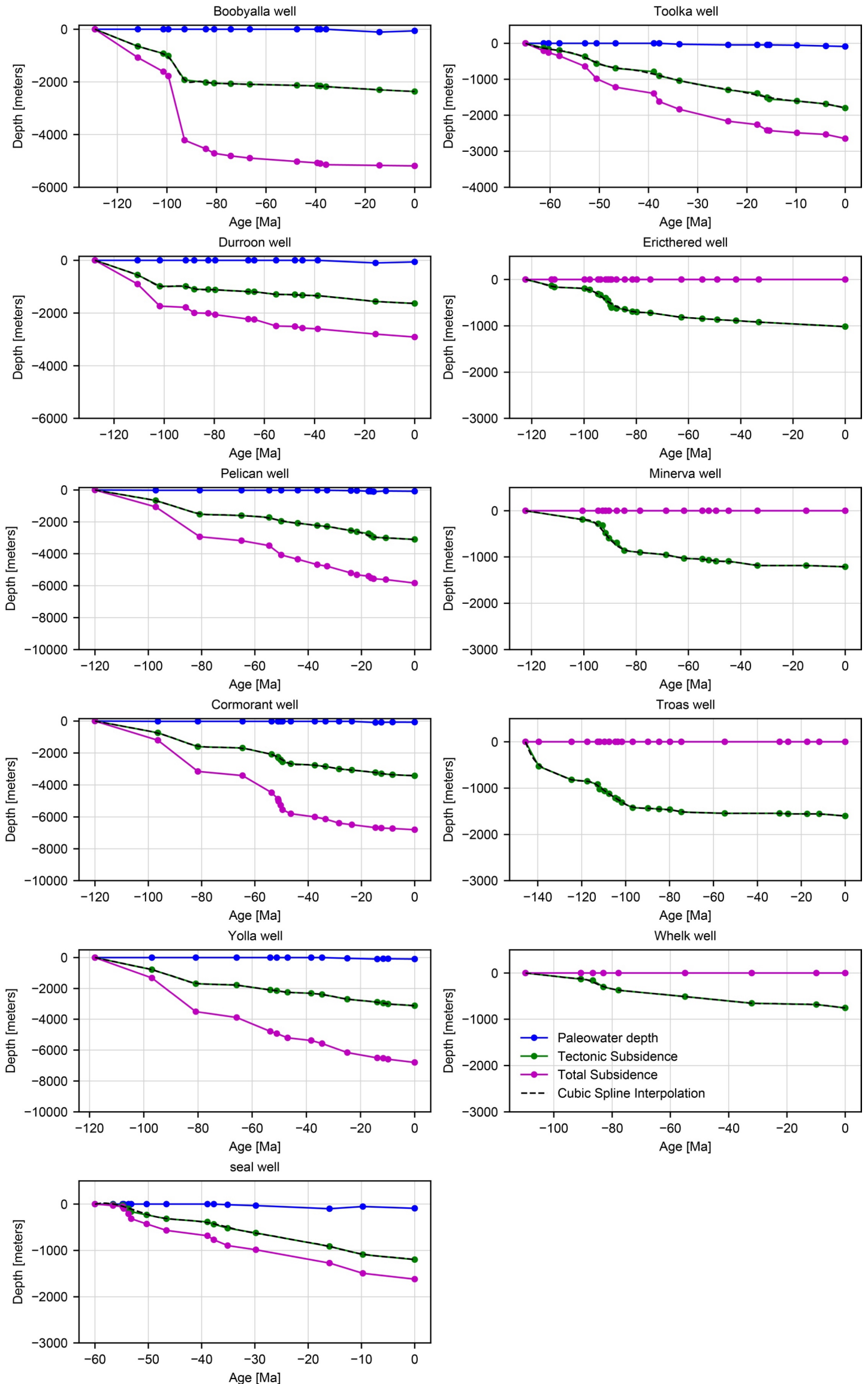

585 Figure S6 -Subsidence data of the studied wells in the Southeast Australia. 
References:

Adda, G. W., Atta-Peters, D., \& Ben-Awuah, J. (2015). Burial History, Thermal Maturity and Petroleum Generation History of the Lower Paleozoic Petroleum System in the Saltpond Basin, Offshore Ghana. Search and Discovery.

Amobi, J. O., Okogbue, C. O., Mode, A. W., Ofoma, A. E., Dim, C. I., \& Okwara, I. C. (2019). Regional 1D hydrocarbon maturation modelling of the Cenomanian-Turonian Lokpanta Shale, southern Benue Trough, Nigeria: Implications for the origin of Niger Delta deep sea oils. Journal of Earth System Science, 128(7), 1-17.

Argent, J. D., Stewart, S. A., Green, P. F., \& Underhill, J. R. (2002). Heterogeneous exhumation in the Inner Moray Firth, UK North Sea: constraints from new AFTA $®$ and seismic data. Journal of the Geological Society, 159(6), 715-729.

Böttner, C., Berndt, C., Reinardy, B. T., Geersen, J., Karstens, J., Bull, J. M., ... \& Haeckel, M. (2019). Pockmarks in the Witch Ground Basin, central north sea.Geochemistry, Geophysics, Geosystems, 20(4), 1698-1719.

601

602

Brown, B. J., Müller, R. D., \& Struckmeyer, H. I. M. (2001). Anomalous tectonic 603 subsidence of the southern Australian passive margin: response to Cretaceous dynamic topography or differential lithospheric stretching?

Chen, A., Jin, C., Lou, Z., Chen, H., Xu, S., Huang, K., \& Hu, S. (2013). Salt tectonics 606 and basin evolution in the Gabon Coastal Basin, West Africa. Journal of Earth Science, 24(6), 903-917.

607

608

Contreras, J., Zühlke, R., Bowman, S., \& Bechstädt, T. (2010). Seismic stratigraphy and 609 subsidence analysis of the southern Brazilian margin (Campos, Santos and Pelotas basins). Marine and Petroleum Geology, 27(9), 1952-1980.

610 D'IVOIRE, C. Ô. T. E. Geology and Total Petroleum Systems of the Gulf of Guinea 611 Province of West Africa.

612 Dressel, I., Scheck-Wenderoth, M., \& Cacace, M. (2017). Backward modelling of the 613 subsidence evolution of the Colorado Basin, offshore Argentina and its relation to the evolution 614 of the conjugate Orange Basin, offshore SW Africa. Tectonophysics, 716, 168-181.

615 Gonzaga, F. G., Gonalves, F. T. T., \& Coutinho, L. F. C. (2000). AAPG Memoir 73, 616 Chapter 13: Petroleum Geology of the Amazonas Basin, Brazil: Modeling of Hydrocarbon 617 Generation and Migration.

618 Justwan, H. (2006). The Petroleum Systems of the South Viking Graben, Norway. 
619 Justwan, H., Meisingset, I., Dahl, B., \& Isaksen, G. H. (2006). Geothermal history and 620 petroleum generation in the Norwegian South Viking Graben revealed by pseudo-3D basin 621 modelling. Marine and Petroleum Geology, 23(8), 791-819.

622 Kaki, C., d'Almeida, G. A. F., Yalo, N., \& Amelina, S. (2013). Geology and petroleum 623 systems of the offshore Benin Basin(Benin). Oil \& Gas Science and Technology-Revue d'IFP 624 Energies nouvelles, 68(2), 363-381.

625 Lopes, J. A., de Castro, D. L., \& Bertotti, G. (2018). Quantitative analysis of the tectonic 626 subsidence in the Potiguar Basin (NE Brazil). Journal of Geodynamics, 117, 60-74.

627 Mackay, L. M., Turner, J., Jones, S. M., \& White, N. J. (2005). Cenozoic vertical motions 628 in the Moray Firth Basin associated with initiation of the Iceland Plume. Tectonics, 24(5).

629 Meredith, W., Uguna, C. N., Snape, C. E., Carr, A. D., \& Scotchman, I. C. (2020). 630 Formation of bitumen in the Elgin-Franklin complex, Central Graben, North Sea: implications 631 for hydrocarbon charging. Geological Society, London, Special Publications, 484(1), 139-163. 632 Morales, E., Chang, H. K., Soto, M., Veroslavsky, G., Conti, B., Ana, H. D. S., \& Corrêa, 633 F. S. (2017). Speculative petroleum systems of the Punta del Este Basin (offshore 634 Uruguay). Brazilian Journal of Geology, 47, 645-656.

635 Stewart, J., Watts, A. B., \& Bagguley, J. G. (2000). Three-dimensional subsidence analysis 636 and gravity modelling of the continental margin offshore Namibia. Geophysical Journal 637 International, 141(3), 724-746.

638 Turner, J. P. (1995). Gravity-driven structures and rift basin evolution: Rio Muni Basin, 639 offshore equatorial West Africa. AAPG bulletin, 79(8), 1138-1158. 